\title{
Large format stores and the introduction of new Regulatory controls
}

\author{
in South Korea
}

\section{Woohyoung Kim Alan G Hallsworth}

Senior Researcher, Research Team for Commercial Districts Development, Agency for Traditional Market Administration, Small Medium and Business Administration

E-mail:pony30@sogang.ac.kr

Professor, Visiting researcher, Portsmouth Business School, University of Portsmouth E-mail: alan.hallsworth@port.ac.uk

Abstract: Since 1996, when Korea's retail industry was liberalised, new store formats such as large discount stores, grew, it was widely believed, at the expense of incumbent rivals such as traditional markets and small operators. This paper seeks to empirically test this proposition: an important underpinning to new regulatory control policies. Research involved a spatial analysis of traditional markets $(1,456)$, large discount stores (408), and SSMs (super-supermarkets or hypermarkets (729)) spread throughout the country, in order to examine the scale and scope of the influence of the new retail store formats. The research is supportive of the 'Traditional Commercial Activity Protection Zones', which protect small and medium-sized enterprises (SMEs). From the perspective of traditional markets, it may be necessary for the South Korean government to promote additional, more proactive, support policies for SMEs.

\section{Key words: Retail Industry, Korea, TNCs, SME, GIS}

\section{South Korean retail change: our approach.}

The case of South Korea commands interest for several reasons. If our interest lay purely with globalisation then the rapid rise of South Korea, in barely half a century, to become one of the world's great exporters of products including automobiles (Hyundai, Kia etc) and consumer electronics (dominantly Samsung) would demand inclusion. Our more modest concerns, however, relate to the domestic implications for 
South Korea of inward retail investment since liberalisation in 1996. Note that Dawson (2007 p 373) explicitly bemoaned "the absence, in international retailing, of concept and theory that does not hang on the coat-tails of international production" before going on to theorise the problem and offering (2007 p393) four dimensions of change. (see also Dawson 2003, Dawson and Mukoyama. 2006). The changes that we consider could be theorised as part of the diffusion of retail innovations literature (for example, Kaynak, 1985). Equally, literature on global retail capital and financialisation would provide a suitable underpinning - as would literature on trade regulation since the political economy of world trade is a topic to fascinate. Together, the demands that trade be more overtly two-way and also the Asian financial crisis served to prise open certain Asian retail markets (Reardon et al 2003, Reardon et al 2007). As Wrigley and Lowe (2010) have noted, such trends can explicitly be linked to the activities of specific transnational retail firms (see also Coe and Wrigley (eds) 2009). In a useful summary of globalisation trends they cite South Korea as one of four emerging markets entered by UK retailer Tesco. Again, however, our concern lies less with the process of inward retail investment than it does with how a host nation may react. Two further approaches thus suggest themselves. There is, firstly, the regulatory role of the state. Indeed, Dawson (2007) alluded to this by questioning if policy makers should seek to devise policies that would provide time for local retailers to adjust to new competitive conditions. Such policies need not explicitly be linked to inward retail competition as Burt's (1984) work on the Loi Royer in France demonstrated. Tesco's 'home' country has not hesitated to regulate the activities of domestic and other retailers in the past (Hallsworth 1998) and a 1996 regulation - the sequential test which covers large stores - remains in force. This suggests an ongoing role for 'real regulation': government-driven legislation. Our second particular 
interest lies with the extent to which the host country is amenable, or otherwise, to the presence of newcomers. Though the late Arieh Goldman wrote extensively on Asian retail topics (see, for example, Goldman 2001), we especially draw attention to a 1999 paper by Goldman et al. Goldman was interested in how the 'wet markets' of Hong Kong might be so distinctive as to defy attempts by new rivals to lure away their customers. As will be seen below, others have commented on the loyalty of South Koreans to their traditional markets. This reinforces the view that barriers to entry need not be regulatory - though they often are (Wrigley and Lowe 2010 pp 22-24).

For us then, the fact of market entry into South Korea by global retail giants is a given. Our focus is on regulatory responses aimed at ameliorating the effects of these changes on existing, traditional retail systems. That said, much useful information does exist as a result of research on the inward investors themselves. Consideration of such findings leads us to endorse the work of those who stress the importance of territorial embeddedness. Indeed, without such strategies, there might be little by way of successful inward retail investment to concern the host nations.

In focusing on regulation we parallel Kim D-R (2011 p1038) who noted 'the devolution in 1995 of environmental enforcement in South Korea' before commenting (2011 p 1050) that outcomes are 'contingent upon the broader politicoeconomic context'. We agree entirely and would add a further coda, introduced by Wortmann (2004). This is that, whilst jurisdictions almost never protect individual local enterprises per se from new 'efficient' competition - unless the latter behave unfairly or anti-competitively - they do seek to preserve whole entrepreneurial sectors such as SMEs. Understandably so: SME activity underpins large corporations across the globe: often working closely with them. Wortman demonstrated that the policy in Germany did not discriminate between defending the value offered by industrial 
SMEs and by retail SME's. In Korean retailing, the change that drives the need for regulation has, on our time-frame, been provided by three transnational retailers from Europe and North America: Tesco, WalMart and Carrefour. Turning to our second theme we find that researchers viewing the topic from the entrants' perspective - Coe and Lee (2006) - have also noted the factor of the inherent receptiveness of the host nation. In respect of South Korean consumers, they noted (2006 p 77) 'The customers' strong nationalistic outlook and sentiments against foreign capital' and presciently, 'WalMart and Carrefour are perceived to be poor at responding to local customer's tastes' (see also Kim and Jin 2001 and Kim R B 2008). They characterised the fact that Tesco entered Korea in 1999 (later than WalMart and Carrefour) via a joint venture with Samsung as territorial embeddedness and, especially, 'strategic localisation'. In 2012, of these three major international firms, only Tesco remains in South Korea. So, major retail TNCs, often with decades of experience in running freestanding large format stores in Western Europe and North America (Hallsworth and Evers 2002) export competencies, such as global production networks (GPN), IT technology and management know-how but may still be at the mercy of local factors. Coe and Lee (2006 p 77) wrote of initial low staff morale but local effects work often in subtly different ways - not all of which spell success. Two big arenas for such expansion are the growing BRIC economies and also the spectacularly deregulated former Soviet Bloc countries such as the Czech Republic and Poland. The politicoeconomic context - and a lack of strong local incumbents - has led the latter to grant the growth in their retail industry to TNCs, whereas our case study, South Korea, has seen competition with TNCs lead to a strong fightback by incumbent domestic retailers.

\subsection{Real regulation}


Returning to the issue market regulation, we do not have space here to cover the plethora of ways by which Governments can regulate retail markets. For example, Germany used store size limits and Japan utilised zoning laws to control the expansion of allegedly more productive, large-scale discounters (Boylus and Guiseppe 2001). Liberalisation, too, can take many forms: including easing of regulations on opening hours or relaxation of merger and competition laws. As noted, the Korean government liberalised the distribution market in 1996 whereupon a number of foreign retailers entered the market bringing in their large format stores. Here we focus on the impact on traditional markets rather than on specific individual small shops and find that decline was most prominent among small and medium-sized distributors. The number of traditional markets decreased by $11 \%$ from 1,695 (KRW 36 trillion in revenue) to 1,517 (KRW 24 trillion), whilst the number of large discount stores sharply increased from 265 (KRW 19.6 trillion in revenue) in 2003 to 442 (33.7 trillion) in 2010. Not all agree on the scale and nature of decline following policy liberalisation nor on whether or not jurisdictions should intervene proactively. According to SMBA (2010), however, the Korean government provided financial support of USD 19 billion for 777 traditional markets to renovate facilities and improve market quality: paralleling practices found in, for example, Catalunya, Spain. However, (see also DCLG 2010) sales in traditional markets continue to decrease despite governmental support and efforts, whereas the sales of competitors such as large discount stores, supermarkets, and SSMs continue to increase. The new wave of large discount stores and SSMs in the Korean distribution market has certainly led to a general restructuring though there remain other underlying factors. Key among them (Kim W 2011) is the Korean government's development policy which induces concentration of population in the Seoul area (see also Kim and Donaldson, 1979, Kim 
and Kim, 2000). This growth acts as a magnet for large-scale retail store formats to open in the most populous cities - putting concentrated pressure on incumbent traditional markets ${ }^{1}$. The vital SMEs are thus declining in Korea's distribution industry. To examine this phenomenon we offer an empirical case study which shows the effect of government-led regulations to restrict retail conglomerates in order to safeguard SME retailers. We map the changes in the retail system caused by TNCs and revitalized domestic conglomerates and by analyzing the change based on population and floor space. This research also examines the effect of 'last resort' regulation laws established by the Korean government to assist SMEs through restrictions on both franchise stores and those stores under the direct management of conglomerates. Korean government action to correct market distortions affecting retail SMEs has become politically inevitable. As noted, SME activity is universally seen as beneficial and according to the OECD (2010), Korea's self-employment rate is currently high at $28.8 \%$.

We now consider the evidence base on how structural changes among different types of distributors (large discount stores, SSMs, and traditional markets) influence the competitiveness of Korean retail industry. First, we analyze the spatial locations of large discount stores SSMs, and traditional markets using a GIS technique. We utilize this to analyze spatial competition among retailers and then seek to assess the impact of the so-called SSM regulation laws enacted by the Korean government. We then provide policy suggestions through which the Korean government might in future efficiently support traditional markets and SMEs.

\footnotetext{
${ }^{1}$ As of 2010, Korea's total population is 48.5 million, 23.8 million of which reside in Seoul and Incheon. Thus, $50 \%$ of the total population lives in the capital area (National Statistical Office, 2010).
} 


\section{Emergent markets and the western retail invasion.}

On our time frame - since the early 1990s - transnational retailers such as Tesco, Carrefour and WalMart have used merger and acquisition activities to secure dominant market positions in developing countries. A notable pull factor was that, in the 1990s, personal disposable income in developing countries increased and TNCs drove retail restructuring by introducing large discount stores and super-supermarkets (SSMs). Such changes occurred in Southeast Asia, Northeast Asia, Latin America, and, as noted, Eastern Europe. 
Table 1 The Competitive Structure 2009/10 of 9 Emerging Markets

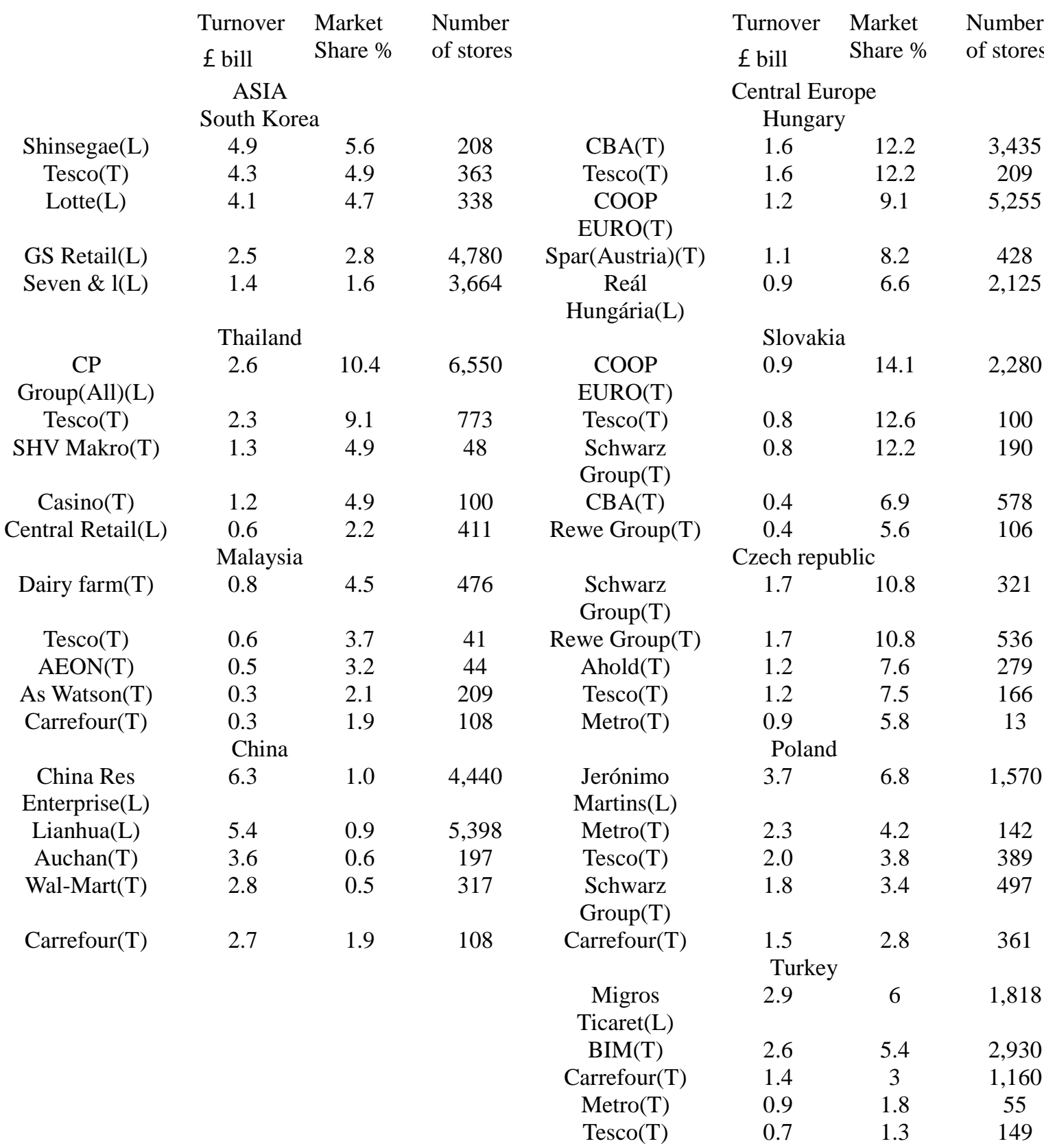

Source: Adapted from Bank of America/Merrill lynch, 10 Sept 2010 (after: OECD , 2010), TNCs(T), Local Firm(L)

$<$ Table 1> depicts key features of TNCs' overseas expansion into Asian and Eastern European markets. Note that Eastern European markets have become dominated by TNCs from Western Europe. In the case of Hungary, TNCs swept the top 4 rankings in terms of net profit and market share, whereas in Slovakia and Czech 
Republic, TNCs from Western Europe swept the top 5 rankings. Western European TNCs in Southeast Asia took rankings 2 to 4 in Thailand with $18.9 \%$ of the market share, and, in Malaysia, TNCs claim the top 5 rankings occupying $15.4 \%$ of the market share. In China, TNCs occupy the rankings from No. 3 to No. 5, but their market share is not very large due to the immense scale of the Chinese distribution market.

South Korea makes a noteworthy retail case: the only remaining TNC is Tesco, which ranks No. 2 with a market share of $4.9 \%$. and the rest of the top 5 are Korean conglomerates. The market share occupied by Korean conglomerates amounts to $14.7 \%$, and the number of stores operated by these players is $8,990^{2}$. Note that the market share of the top 5 is very low compared to the much-more-concentrated UK market where Tesco alone holds over $30 \%$. Why then, did TNCs fail to dominate Korea? Wal-Mart, Carrefour, and Tesco entered the Korean distribution market when the Korean government liberalised in 1996 but, as noted, only Tesco remain because, in 2006, Wal-Mart and Carrefour both withdrew from the Korean market. Confirming the view of Coe and Lee (2006) on the importance of territorial embeddedness, it appears that they entered the Korean market without a thorough prior analysis of Korea's incumbent retail conglomerates, which had strong distribution network, sales know-how, and capital. The Korean economy in general developed through public companies and conglomerates initiated by government in the 1970s and 1980s. By the time the retail TNCs arrived, retail distribution was already dominated by a handful of conglomerates, such as Shinsegae, Lotte, LG and Hyundai. As a result, TNCs suffered difficulties in finding good new locations and in competing with strong local incumbents. Second, some failed to meet the needs of Korean customers but

\footnotetext{
2 7-11 was originally an American company, which was acquired by Lotte Shopping, which is a Korean conglomerate, in 1994.
} 
adamantly stuck to their accustomed strategies. WalMart - who also withdrew from

Germany - found that their business model failed in Korea due to not understanding, nor meeting, local needs. Instead of building a strong alliance with local suppliers in Korea, they supplied products through collaboration with pre-established overseas suppliers, which resulted in failure to supply products that met the preferences and tastes of Korean customers. Carrefour deployed CEOs and executives from France to promote sales, but failed to survive in the race with competitors and eventually withdrew from the Korean market. Korea's distribution market remains a peculiar space where conglomerates have $70-80 \%$ of market power in the overall distribution industry which is dominated by department stores and large discount stores. Fears that foreign TNCs might dominate the Korean distribution industry post-1996 were therefore not realized. Instead, foreign TNC entry into the Korean market incentivised local conglomerates to strengthen their own large store formats - and hence market power and competitiveness. It is clear that this came at the expense of SMEs.

\section{Analysis of the Competitive Landscape of Space among Retail Store Formats}

\subsection{Data development}

The importance of location in retail business has been emphasized in many studies (Clarke et al., 1997: Simkin et al 1985 Bowlby et al., 1984 Jones and Simmons 1987). We next analyze the locational characteristics of traditional markets, large discount stores and SSMs. We first collected location-related data based on the addresses of retailers via the Small \& Medium Business Administration database (www.smba.go.kr) for information on traditional markets, and "The Yearbook of Retail Industry 2010” for large discount stores and SSMs. We collected location data 
for 1,456 traditional markets, 408 large discount stores, and 729 SSMs. To turn such location data into spatial data, we used ArcGis 9.3; we first combined the addresses of the retailers with the land registration map (parcel) of the Korea Land Information System (KLIS); then we converted the locations of each individual market into points based on the midpoint of the record of the land registration. We used the Dasymetric Mapping technique suggested by Applebaum (1968) to convert the population numbers of eup(town), myeon(township), dong(neighborhood) into spatial data by rasterization. The 2009 Land Cover Map (LCM), provided by the Korean Ministry of Environment, was used to obtain the data. Utilising Choi et al's., (2010) method, populations at the raster cell level are estimated using the following equation:

$$
A_{i}^{e}=\omega_{r} \alpha_{k} K_{i}
$$

where $A_{i}^{e}$ denotes population estimates of the raster cell $i, \omega_{r}$ denotes a locally weighted value for tract $r$, which denotes the eup (town), myeon (township), and dong (neighborhood) that the raster cell $i$ belongs to, and $\alpha_{k}$ denotes estimated population coefficient for the land use which is denoted as $k$. As for $K_{i}, K_{i}$ equals 1 if the land use of the raster cell $i$ is $k$, whereas $K_{\bar{i}}$ equals 0 in all other cases. Also, the locally weighted factor $\left(\omega_{r}\right)$ is a controlling coefficient to ascertain that the total population counts of all raster cells belonging to tract $r$, which denotes the eup (town), myeon (township), or dong (neighborhood) coincides with the original population count of tract $r$. It can be derived using the following equation:

$$
\omega_{r}=\frac{\text { Actual }_{r}}{\sum_{k} \sum_{i=r} \alpha_{k} K_{i}}
$$

where $\alpha_{k}$ denotes the regression equation estimate of the ordinary least square of population on the area of land use ( $k$ ) from the land use situation map. The scope of land use was determined by utilizing only residential areas among types of land use. The size of the raster cell depends on the spatial resolution of the land use situation 
map, but in this study, it was determined as $20 \mathrm{~m} \times 20 \mathrm{~m}$. A regression analysis after eliminating the $\mathrm{x}$-intercept presented an estimate of 0.0182 and $\mathrm{r}$-square of 0.25 at a significance level of $0.01 \%$.

\subsection{Process and contents for Analysis}

Data on traditional markets, large discount stores, and SSMs are built using a Geographic Information System (GIS) of the sort used in retailing since the 1980s (Goodchild, 1991). A population density map for the analysis of spatial competition between businesses is made using the advantages (speed, the comprehensive range of data available, quality controls, and data continuity) of the GIS suggested by Clarke and Rowley (1995). Next, the location characteristics of the different types of retailers are examined by time period; then, we analyze the locations of large discount stores and SSMs in the new Traditional Commercial Activity Protection Zones ${ }^{3}$. Based on this, an analysis of regions where SSMs are additionally permitted to locate is conducted. In order to analyze spatial competition between traditional markets and large discount stores and the spatial competition between traditional markets and SSMs, the business districts are first analyzed by type of retailers. Therefore, we set a distance of $800 \mathrm{~m}$ between traditional markets and SSMs and $3 \mathrm{~km}$ between traditional markets and large discount stores, using the business district radiuses presented in the Ecology Environment City Manual of The Korea Land \& Housing Corporation.

\footnotetext{
${ }^{3}$ The Korean government amended the Distribution Industry Development Act on Nov 24, 2010, and designated traditional market preservation zones to protect and preserve the tradition and history of the local distribution industry. According to the law, a superstore is not allowed to locate within a distance of $500 \mathrm{~m}$ from a traditional market or retail store, pursuant to the Special Act for Promotion of Traditional Markets and Retail Stores (Article 13-3 of the Distribution Industry Development Act of Korea).
} 


\subsection{Analysis of spatial location characteristics by types of retailers}

As noted elsewhere, Zhu and Singh (2009), large discount stores and SSMs in Korea are located in the most convenient and accessible areas whilst Figure 1 shows that traditional markets are more evenly distributed nationally. This is because, historically, traditional markets took conventional locations at the center of any commercial or cultural area. Overall, in Korea, $98.8 \%$ of large discount stores and 97.1\% of SSMs are located in cities. In particular, large discount stores are evenly distributed without distinction between the original center and sub center of the city in Korea. This implies that most large discount stores are city-centered. On the other hand, most traditional markets are shown to be located in big cities with a high population density. The data show that $79.3 \%$ of traditional markets are located in cities. Therefore, it is highly likely that the traditional markets located in cities will decline rapidly in the face of new competition.

\section{Figure 1. Location by type of retailer}

\section{Locations of large discount stores and SSMs by time period}

Large discount stores and SSMs that are in competition with traditional markets have increased in number over the last 15 years (1995 2009). There were only 13 large discount stores in 1995, but the number had grown to 375 stores in 2009. During the same period, their sales area grew rapidly from $109,923 \mathrm{~m}^{2}$ to $3,072,607 \mathrm{~m}^{2}$. After the mid-2000s, the number of large discount stores increased more

slowly because there were not many regions left with the requisite population to support large discount stores. The increase in the number of SSMs is not as high as the increase in the number of large discount stores, but the speed of their growth is 
remarkable. In 1995, there were only 46 SSMs, but this number increased to 675 by 2009. During the same period, the area of sales increased from $45,132 \mathrm{~m}^{2}$ to $565,963 \mathrm{~m}^{2}$ . SSMs are not increasing their sales area as fast as the number of stores: implying that more smaller format stores are now opening.

\section{Figure 2. Spatial locations of the large discount stores $(2000 \sim 2009)$}

From a wider perspective, there is a similarity in the spatial expansion of large discount stores and SSMs. In 2000, most large discount stores and SSMs were located in metropolitan areas and in five metropolitan cities. However, since 2005, they have been expanding into smaller regions. Between 2005 and 2009, many large discount stores and SSMs opened in provincial cities : notably in Gyeonggi province. Korea makes a further interesting contrast with the US experience of WalMart which opened its first stores in small and medium-sized cities with populations of 25,000 or less and thus adopted a reverse hierarchical strategy with major elements of contagious diffusion (Graff and Ashton, 1994,Graff, 1998). Conversely, Korea's large discount stores entered large cities first and then expanded to small and medium-sized cities with populations of 100,000 or more: hence following a more typical hierarchical diffusion strategy.

\section{Figure 3. Spatial location of SSMs $(2000 \sim 2009)$}

\section{Area and population-based spatial competition}

By our analysis, the spatial competitive area between the traditional markets and the large discount stores is $975 \mathrm{~km}^{2}$. This is twice as large as the competitive area 
of $437 \mathrm{~km}^{2}$ between the traditional markets and the SSMs. Spatial competition based on area is more intense in metropolitan areas, where there are many kinds of retailers. The following list of cities, by size order, demonstrates intense spatial competition between traditional markets and large discount stores: Seoul $\left(179 \mathrm{~km}^{2}\right)$, Busan $\left(152 \mathrm{~km}^{2}\right.$ ), Daegu $\left(86 \mathrm{~km}^{2}\right)$, Incheon (56 km²), Daejeon (33 km²), Gwangju (30 km²), and Ulsan (29 $\left.\mathrm{km}^{2}\right)$. The more traditional markets and large discount stores that are located in an area, the more intense the spatial competition. However, there is a large deviation in the spatial competitive areas of regions that have many traditional markets and large discount stores. In order to analyze this interesting phenomenon, we selected regions with more than five traditional markets and three large discount stores. The resulting order of regions that have low spatial competition between traditional markets and large discount stores is as follows: Gumi $\left(4.0 \mathrm{~km}^{2}\right)$, Cheon'an $\left(5.2 \mathrm{~km}^{2}\right)$, Iksan $\left(5.6 \mathrm{~km}^{2}\right)$, Suncheon $\left(5.9 \mathrm{~km}^{2}\right)$, Paju $\left(6.8 \mathrm{~km}^{2}\right)$, Sungnam $\left(7.3 \mathrm{~km}^{2}\right)$, Yeosu $\left(8.8 \mathrm{~km}^{2}\right)$, and Jeju $\left(10.0 \mathrm{~km}^{2}\right.$ ). The locations of the large discount stores in these regions do not appear to have been decided according to a plan, but at least these large discount stores have less of a negative influence on traditional markets than do the large discount stores in other regions. Regions that have intense spatial competition between traditional markets and SSMs show similar results on the competition between traditional markets and the large discount stores, but there are slight differences among these intensely competitive regions. The rank order of regions showing intense spatial competition between traditional markets and SSMs is as follows: Seoul $\left(108 \mathrm{~km}^{2}\right)$, Busan $\left(73 \mathrm{~km}^{2}\right)$, Daegu (23 km²), Daejeon $\left(18 \mathrm{~km}^{2}\right)$, Pohang (12 km²), Incheon $\left(12 \mathrm{~km}^{2}\right)$, Changwon $\left(11 \mathrm{~km}^{2}\right)$, 
and Bucheon $\left(11 \mathrm{~km}^{2}\right)$. We also conducted an analysis of cities and kun with low spatial competition between traditional markets and SSMs and with more than five traditional markets and SSMs. The results show that there is very little spatial competition between traditional markets and SSMs in cities like Cheon'an $\left(1.4 \mathrm{~km}^{2}\right)$, Jeonju $\left(2.0 \mathrm{~km}^{2}\right.$ ), Jinju $\left(2.1 \mathrm{~km}^{2}\right)$, Chuncheon $\left(3.1 \mathrm{~km}^{2}\right)$, and Gumi $\left(3.2 \mathrm{~km}^{2}\right)$. According to the analysis, traditional markets located in these cities are less negatively influenced by the locations of SSMs.

\section{Population-based analysis}

We have analyzed the spatial competition between traditional markets and large discount stores and that between traditional markets and SSMs, based on population. The results of our analysis are as follows: the population of regions with spatial competition between traditional markets and large discount stores and between traditional markets and SSMs is 16,610,000 and 8,810,000, respectively. Based on population, the spatial competition between the traditional markets and the large discount stores is found to have intensified to nearly double that between the traditional markets and SSMs. This is because the business districts of large discount stores are much larger than those of SSMs. Cities show strong characteristics in spatial competition based on population. Intense spatial competition between traditional markets and large discount stores is shown in the following regions, according to population (provided in brackets): Seoul $(4,900,000)$, Busan $(2,530,000)$, Daegu (1,380,000), Incheon (1,300,000), Bucheon (590,000), and Daejeon (500,000). As with spatial competition based on area, we analyzed the regions that show the weakest spatial competition between traditional markets and large discount stores, 
based on population. For this analysis, we selected regions with more than five traditional markets and three large discount stores. From our results, the order of regions with the weakest spatial competition between traditional markets and large discount stores, based on population (provided in brackets) is as follows: Paju $(44,000)$, Pyeongtaek $(45,000)$, Gumi $(46,000)$, Chuncheon $(47,000)$, and Suncheon $(50,000)$. In these regions, traditional markets are not seriously influenced by large discount stores. Accordingly, spatial competition between traditional markets and SSMs, based on population, is similar to the spatial competition between traditional markets and large discount stores. Again, this is because most large discount stores and SSMs are located in big cities.

Figure 4 Spatial Competition Population among the Traditional Market, Large Discount Stores, and SSMs

Figure 5 Spatial Competition Region among the Traditional Market and Large Discount Stores, and SSMs

\section{Measurement of Effect of SSM Regulation Law}

\subsection{Purpose of Analysis: effective real regulation.}

Through an amendment to the existing 'Distribution Industry Development Law' of 2011, policy has been enacted to protect traditional markets through the establishment of Conventional Commerce Preservation Districts (CCPDs) regulating the location of large retail formats within a $1 \mathrm{~km}$ radius from the boundaries of traditional markets (http://smba.co.kr). It is a fully-fledged location management policy to preserve traditional markets. The establishment of these CCPDs has directly influenced the growth of SSMs. Essentially, a social consensus existed that the rapid growth of large format retailing was causing decline in traditional markets and so preservation districts were introduced. We next examine the status of large discount 
stores and the SSMs located in CCPDs. This illustrates potential limitations and difficulties faced by location policies that seek to preserve traditional markets. Furthermore, we will utilise our spatial analysis to suggest possible permitted locations for new SSMs. This carries some parallels with the UK's so-called sequential test (Baldock 2000) and underlines the necessity to monitor the location of SSMs which may compete with traditional markets. From the perspective of spatial planning, by premptively analyzing the regions where new stores might locate, a more effective location policy can be implemented. Analyzing the possible locations for new SSMs is a suitable procedure to help preserve traditional markets.

\subsection{Location Status of Large Retail Stores and SSMs in CCPDs}

As mentioned above, for the purpose of preservation of traditional markets, through the amendment of 'The Distribution Industry Development Law' in 2010, the opening of large scale stores within a $500 \mathrm{~m}$ radius from traditional markets was limited for the following 3 years. Also, in 2011, the CCPD area was expanded from $500 \mathrm{~m}$ to $1 \mathrm{~km}$. Based on the same law, there is a necessity to measure what effects the regulations covering $500 \mathrm{~m}$ and $1 \mathrm{~km}$ actually have. Our approach is to analyze CCPDs of $500 \mathrm{~m}$ and $1 \mathrm{~km}$ using the GIS to execute a Buffer Analysis. Inevitably this shows that regions with more traditional markets have more CCPDs and are especially concentrated on the Seoul Metropolitan Region plus the 6 metropolitan cities and the large cities in the regional areas. When examining the conventional commerce preservation district $(500 \mathrm{~m})$ based on the spatial size of each city, the findings are as follows. They were, in order, Seoul City $\left(9,317 \mathrm{~m}^{2}\right)$, Busan City $\left(6,980 \mathrm{~m}^{2}\right)$, Daegu City 
and Daejeon City $\left(1,322 \mathrm{~m}^{2}\right)$. On June 30, 2011, the government expanded the district from $500 \mathrm{~m}$ to $1 \mathrm{~km}$ because it was felt that CCPds of $500 \mathrm{~m}$ did not offer enough protection for traditional markets. Using the GIS, our research analyzed the spatial size of the area included in the CCPD with the radius expanded from $500 \mathrm{~m}$ to $1 \mathrm{~km}$. The resulting ranking was: Seoul City $\left(25,011 \mathrm{~m}^{2}\right)$, Busan City $\left(17,330 \mathrm{~m}^{2}\right)$, Daegu City $\left(12,904 \mathrm{~m}^{2}\right)$, Incheon City $\left(7,833 \mathrm{~m}^{2}\right)$, Ulsan City $\left(6,159 \mathrm{~m}^{2}\right)$, Gwangju City $\left(2,765 \mathrm{~m}^{2}\right)$, and Daejeon City $\left(4,018 \mathrm{~m}^{2}\right)$, and showed a general increased ratio of 2 3 times.. When the CCPD is set at a radius of $1 \mathrm{~km}$, the total area with traditional markets at their centres covered a net spatial size of $2,490 \mathrm{~km}^{2}$. It showed an increased rate of 3 times $\left(1,714 \mathrm{~km}^{2}\right)$ compared to when it was $500 \mathrm{~m}\left(776 \mathrm{~km}^{2}\right)$. In the case of Seoul City and the 6 metropolitan cities the total size was $824 \mathrm{~km}^{2}$, showing a $495 \mathrm{~km}^{2}$ increase compared to the $500 \mathrm{~m}$ radius $\left(328 \mathrm{~km}^{2}\right)$, showing the effects of a threefold increase. The number of large retail stores in the CCPD is 79 , which is $19.4 \%$ of the total of 408 . Based on major cities, there were large retail stores located in the CCPDs in 30 regions: in order - Busan City (19), Seoul City (15) Daegu City (7), and Ulsan City (5). The number of SSMs in CCPDs was 213, which is $29.2 \%$ of the total number of stores (729). Based on these results, it can be confirmed that the location management policies for SSMs which are in competing relations with traditional markets were insufficient. SSMs were located in the CCPDs in 56 regions in total, and the number of SSMs was larger in the major cities: likewise the number of large retail stores. Again in order : Seoul City (57), Busan City (38), Daegu City (12), Daejeon City (9) and Changwon City 
and Pohang City (8). The ratio of SSMs located in the CCPDs compared to the total number of SSMs showed a large deviation depending on the regions, similar to the large retail stores. Although the number of SSMs was only one or two, the number of cities where SSMs are located in the CCPDs was found to be 13. The regions are Youngcheon City, Cheolwon Gun, Moongyeong City, Hwasoon Gun, Ye-san Gun, Changnyoung Gun, Cheong-do Gun, Yeoncheon Gun, Hwoengseong Gun, Jincheon Gun, Hongcheon Gun, Yang-gu Gun, and Jeungpyeong Gun. The subsequent regions with a high ratio of SSMs in CCPDs were Changwon City (72.7\%), Pohang City (72.7\%), Gunpo City (66.7\%), Masan City (62.5\%), Gyeongju City (69\%) and Busan City $(55.1 \%)$.

\section{Figure 6 SSMs located in CCPDs}

Figure 7 the finalized possible location for SSMs (Nationwide)

\subsection{Possible New Locations for SSMs}

In essence we see that, as in many other countries, policy has been enacted in response to change that has already taken place. Inevitably, early stores are developed in locations that may later prove to be overly impactful. A more proactive approach - involving a prior search for sites that will be approved - is surely superior. An analysis of such possible new locations for SSMs is now executed: through 5 major phases. In Phase $\mathrm{I}$, the population within an $800 \mathrm{~m}$ radius which is the commercial domain of SSMs is spatially calculated on a nationwide basis. Inevitably, retail store formats tend to locate where a certain level of population can be found. The population necessary to support a SSM was analyzed based on the commercial area $(800 \mathrm{~m})$. After setting the national territory in pixels of $20 \times 20 \mathrm{~m}$ squares, the population within an $800 \mathrm{~m}$ radius was calculated for each pixel. For the analysis, the 
Focal Statistics Tool in the ArcGis 9.3 was used. Predictably, the population of areas which can be called the commercial domains of SSMs were higher in major cities which are densely populated areas. In Phase II, the potential possible locations of SSMs are analyzed.

\section{Figure 8 The finalized possible location for SSMs (Seoul)}

In 2010, the average population an SSM served was 24,092 , and the number of areas with a larger population than this was extracted, revealing that the potential locations of SSMs were concentrated in Seoul City and the 5 metropolitan cities. The major cities in Gyeonggi Province, Cheongju City, and Jeonju City also showed more potential as possible locations for SSMs than other regions. In Phase III, the existing commercial domain of SSMs is extracted. This is because a new SSM is less likely to locate where a rival already exists and so such areas were excluded. We re-utilized results on the commercial domain of SSMs as previously generated. In Phase IV, the CCPD locations are extracted since, from 2011, SSMs are prohibited to locate nearby. Again, we could re-use previously generated data on CCPDs and assess the extent of the increased area of SSM prohibition that results from increasing the CCPDs from a $500 \mathrm{~m}$ radius to a $1 \mathrm{~km}$ radius. Broadly, permissible areas will decrease by half $(49 \%)$ from when the CCPD was set at $500 \mathrm{~m}\left(970,711 \mathrm{~m}^{2}\right)$ In the case of Seoul City and the 6 metropolitan cities, only a spatial area of 271,806 $\mathrm{m}^{2}$ will allow the opening of SSMs, which will show a decrease of more than half $(58 \%)$ over the position controlled by a 500m radius. A large effect is expected in areas other than Seoul City and the 6 metropolitan cities where the advancement of large retail stores and SSMs is at a lower level. 
<Table 2> Comparison of difference in possible locations for SSMs depending on alternatives of conventional commerce preservation districts

$\begin{array}{ccc} & & \left(\text { Unit }: \mathrm{m}^{2}\right) \\ \text { Name of Region } & \text { Comparison of difference in possible locations for SSMs depending on } \\ \text { Within } 500 \mathrm{~m} & \text { Within } 1 \mathrm{~km} \\ \text { Seoul City } & 247,721 & 114,428 \\ \text { Dusan City } & 72,284 & 10,977 \\ \text { Incheon City } & 68,877 & 22,670 \\ \text { Gwangju City } & 119,143 & 51,186 \\ \text { Daejeon City } & 52,257 & 30,234 \\ \text { Ulsan City } & 50,277 & 32,222 \\ \text { Gyeonggi Province } & 32,331 & 10,089 \\ \text { Gangwon Province } & 319,158 & 218,599 \\ \text { North Chungcheong Province } & 8,663 & 6,201 \\ \text { South Chungcheong Province } & 21,807 & 10,776 \\ \text { North Jeolla Province } & 9,522 & 4,339 \\ \text { South Jeolla Province } & 26,125 & 16,511 \\ \text { North Gyeongsang Province } & 15,334 & 11,229 \\ \text { South Gyeongsang Province } & 6,583 & 3,886 \\ \text { Jeju Province } & 25,750 & 6,332 \\ \text { Total } & 6,500 & 1,473 \\ & 970,711 & 496,606\end{array}$

\section{Conclusion and Implications}

Traditional markets in Korea were believed to encounter difficulties because large discount stores and SSMs had expanded their businesses. In order to revive the SME economy, the Korean government now provides tangible and intangible support for declining traditional markets, which are mostly occupied by small business owners. Using a GIS we investigated locational effects of competition among the key players-large discount stores, SSMs, and traditional markets-on the distribution market. Also, we studied the likely positive legislative effects of CCPDs as a protector of retail SMEs (considered as social minorities). Note that, Kompil and Celik (2006), when analyzing the restructuring process of the food retailing in Izmir, Turkey, pointed out that the foremost agent of retail change was the supermarket. Accordingly, 
Kompil and Celik (2006) claimed that the increase of supermarkets had a huge influence on the existing retail pattern and the traditional retail structure. However, our results contrast somewhat with Izmir because we found that, in Korea, spatial competition between traditional markets and large discount stores is much more intense than that between traditional markets and SSMs. We confirmed that the store format with the greatest impact on traditional markets and their SME traders is the large discount store rather than the supermarket. Importantly, too, rivalry is keenest from re-energised local incumbents rather than strictly from TNCs - meaning that protective legislation was not inherently pro-local. When investigating spatial competition between large discount stores and SSMs, we examined the $500 \mathrm{~m}$ zones and found that 79 large discount stores (of 408 retailers, 19.4\%) and 213 SSMs (of 729 retailers, $29.2 \%$ ) were actually located within traditional market preservation zones. This would seem to point to a failure of implementation in respect of the location management policy of large discount stores and SSMs. Therefore, aspects of previous governmental policy on improving the competitiveness of small business owners in traditional markets have been unsuccessful. We suggest that proactive policies - by central and local governments - to better regulate large retail stores are necessary. In March 2012, Seoul City set regulations so that it can limit the operation hours of large retail stores and SSMs (from 12:00 am to 8:00 am) and to mandate closing days to twice a month, and advised legislation to the affiliated 'Gu's. So, regulations on large enterprises such as large discount stores can have real effects. Arguably, many of the regulatory laws which were legislated in developed countries in the 1980s and the 1990s have declined recently: sometimes with lobbying from transnational retailers (Sparks 2008). In some developed countries, local governments still use regulatory laws, but fewer developed countries see their central government 
driving forward regulations on large distribution enterprises. In Korea, however, we find that the latest regulatory laws on large distribution enterprises led by the central government can be effective. However, a more robust long-term agenda for government may be to seek to improve competitiveness of retail SMEs rather than to over-regulate large discount stores or SSMs. In the case of Seoul City, because there are many government agencies and large enterprises in the city, it may be preferable in the long run to introduce Business Improvement Districts (BIDs) as in New York, USA and elsewhere. Although many local governments nationwide are holding various events and festivals with the central government funding, these projects are short-term and unsustainable. Overall, to maximize effective governmental policy support, SME retail business owners need both middle and long term systematic and scientific support. Recall that the pressures were initially thought to come from market entry by TNCs and their large format stores. In 2012, back in one of the source areas for such stores - Europe - Carrefour lost its European market dominance to Schwartz group: dominantly a small format operation.

These results have several political implications. First, the intense spatial competition among traditional markets, large discount stores, and SSMs directly influences the decline of traditional markets. From the perspective of revitalization, the prior inability of government to control locations of large discount stores and SSMs has simply accelerated the decline of traditional markets. Traditional markets are directly influenced by the co-location choices of their competitors. In order to secure long-term survival of traditional markets, the government should maintain regulation on the locations of retailers that are in competition with them but also offer a reasonable selection of locations for SSMs. The government must manage this 
policy strategically. Second, we found that the competition between traditional markets and large discount stores has a stronger influence in traditional markets than does the competition between traditional markets and SSMs. This can be seen as a natural result of the agglomeration economics of large discount stores. From the aspect of revitalization of the traditional markets, however, a policy that can ease the intense competition between traditional markets and large discount stores is urgently required. For example, for areas in which large discount stores are located, collaboration between the large discount stores and traditional markets can be a winwin solution to easing the competition. Therefore, the government should establish win-win measures for traditional markets and their competitors. We accept, of course, that there are many factors which may cause retail SMEs to fail. If more variables such as the internet, home shopping, convenience stores, etc. were to be used as dummy variables in spatial competition analysis, a more precise result might be obtained. Future research should seek to execute spatial analysis whilst considering all the variables which can directly and indirectly cause the decline of SME businesses.

\section{ACKNOWLEDGEMENT}

This research is a revision, with supplements, of the content of "An analysis of Spatial competitions among traditional market, SSMs, and large discount stores and policy measures" by the Agency for Traditional Market Administration, Small Medium and Business Administration (2011). 


\section{< References>}

Applebaum, W. 1968 Store Location Strategy Cases, Addison-Wesley: Reading, MA. Baldock, J. 2000 The Sequential approach to Retail development. Report for NRPF/BCSC/DETR: London

Bowlby, S., M. Breheny and D. Foot, 1984. Store location: problems and methods 1. Retail \& Distribution Management, 12 (5), 31-33.

Boylus O and Guiseppe N 2001 OECD Economic Studies No. 32, 2001, Regulatory Reform in retail distribution

Clarke, I., D. Bennison and J. Pal 1997 'Towards a contemporary perspective of retail location', International Journal of Retail \& Distribution Management, 25(2), 59-69.

Clarke, I. and J. Rowley 1995 'A case for spatial decision-support systems in retail location planning', International Journal of Retail \& Distribution Management, 23(3), 4-10.

Coe N and Lee Y-S 2006 The Strategic Localization of Transnational Retailers: The Case of Samsung-Tesco in South Korea. Economic Geography 82 (1) 61-88.

Coe N and Wrigley N 2009 The globalization of retailing. Edward Elgar: Cheltenham DCLG 2010 Retail Markets: A good practice guide, Department for Communities and Local Government in the UK. 1-17.

Goodchild, M.F. 1991 'Geographic information systems', Journal of Retailing, 67(1), 3-15.

Graff, T O 1998, The Locations of Wal-Mart and Kmart Supercenters: Contrasting Corporate Strategies, The Professional Geographer, Volume 50, Issue. 46-57.

Graff, T. O., and Ashton. D, 1994, Spatial Diffusion of Wal-Mart: Contagious and Reverse Hierarchical Elements, The Professional Geographer, Volume 46, Number 1, 19-28

Hallsworth A G \& Evers D V H 2002 The steady advance of WalMart across Europe and changing government attitudes towards planning and competition, Environment and Planning C, 20 (2) 297-310

Jones, K. G. and Simmons, J. 1987 Location Location Location Methuen: Toronto Kim, C-H and Kim, K-H 2000, political economy of Korean government policies on real estate, Urban Studies 37 (7) 1157-1169.

Kim D-R 2011 Do local policy networks deter the race to the bottom in environmental regulations: the case of South Korea Environment and Planning C, 29 (6) 1037-1053

Kim J-O and Jin, B 2001 Korean consumers' patronage of discount stores: domestic vs multinational discount store shoppers' profiles, Journal of Consumer Marketing, 18 (3) .236-255.

Kim, R B 2008, Wal-Mart Korea: Challenges of Entering a Foreign Market, Journal of Asia-Pacific Business, Vol9, Issue4, 344-357.

Kim S-U and Donaldson, P. 1979 Dealing with Seoul's Population Growth: Government Plans and Their Implementation, Asian Survey, Vol. 19, No.7,. 660-673.

Kim W 2011, The influence of structural changes in a local commercial district on local

consumer consumption behavior in South Korea: Using the Multinomial logit model, 
African Journal of Business Management Vol.5 (11), 4455-4464

Kompil M and H.Murat Celik 2006, Modeling the spatial consequences of retail structure change of Ismir, Turkey. Paper presented to International Conference on Regional and Urban Modeling, Free University of Brussels.

OECD (2011) OECD Factbook 2011 Economic, Environmental and Social Statistics (http://dx.doi.org/10.1787/820502247761)

Reardon, T. P Timmer, C B. Barrett, and J Berdegue, 2003, The Rise of Supermarkets in Africa, Asia, and Latin America, American Journal of Agricultural Economics, 85, 1140-1146.

Simkin, L.P., P. Doyle and J. Saunders 1985 How retailers put site location techniques into operation, Retail \& Distribution Management, 13 (3), 21-26.

Small \& Medium Business Administration, 2008, 2009, 2010 Comprehensive plans for the revitalization of the traditional markets (www:smba.go.kr)

Sparks L, 2008, Commentary: when Tony met Bobby Environment and Planning A 40 $2793-2799$

Zhu T \& V Singh, 2009 Spatial competition with endogenous location choices: An application to discount retailing Quantitative Marketing and Economics, vol. 7(1), pages 1-35, March.

Wortmann M, 2004 Aldi and the German model" Competition and Change 8425 441

\section{REFERENCES ADDED}

Burt S (1984) Hypermarkets in France: has the Loi Royer had any effect? Retail and Distribution Management, 12.1 pp 16-19.

Dawson J A (2007) Scoping and conceptualising retailer Internationalisation Journal of Economic Geography 7 pp. 373-397

Dawson, J. A. (2003) Towards a model of the impacts on retail internationalisation. In J. A. Dawson, M. Mukoyama, S. Chul Choi and R. Larke (eds) The internationalisation of Retailing in Asia, pp. 189-209. London: Routledge-Curzon.

Dawson, J. A., Mukoyama, M. (2006a) Retail internationalisation as a process. In J. A. Dawson, R. Larke and M. Mukoyama (eds) Strategic Issues in International Retailing, pp. 31-50. London: Routledge.

Goldman, A. Krider R and Ramaswami, S (1999) The persistent competitive advantage of traditional food retailers in Asia: wet markets' continued dominance in Hong Kong. Journal of Macromarketing 19.2 126-139

Goldman, A. (2001) The transfer of retail formats into developing economies: the example of China. Journal of Retailing, 77: 221-242.

Hallsworth A G. (1998) "Superstore Impact: not just space but time" Town and Country Planning, 67. 11 pp 352-353 December.

Kaynak, E (1985). Global spread of supermarkets: some experiences from Turkey in E Kaynak (ed) Global perspectives in Marketing NY: Praeger

Reardon T , Henson S and Berdegue J (2007) Proative fast tracking diffusion of supermarkets in developing countries: implications for market institutions and trade. Journal of Economic Geography 7 399-431

Wrigley N and Lowe M (2010) The globalisation of trade in retail services. Report for OECD trade policy meeting, Paris November 